\title{
Urinary arsenic, cadmium, manganese, nickel, and vanadium levels of schoolchildren in the vicinity of the industrialised area of Asaluyeh, Iran
}

\author{
Raheleh Kafaei $^{1}$ - Rahim Tahmasbi ${ }^{2}$ - Masomeh Ravanipour ${ }^{1}$. \\ Dariush Ranjbar Vakilabadi ${ }^{1}$ - Mehdi Ahmadi ${ }^{3,4}$ - Abdolmajid Omrani ${ }^{5}$. \\ Bahman Ramavandi ${ }^{1}$ (D)
}

Received: 7 January 2017 / Accepted: 21 August 2017

(C) Springer-Verlag GmbH Germany 2017

\begin{abstract}
Asaluyeh is one of the most heavily industrialised areas in the world where gas, petrochemical, and many downstream industries are located. This study aims to survey the biomonitoring of four metals and one metalloid in children living in the vicinity of Asaluyeh area. To do this, we analysed the creatinine-adjusted urinary levels of arsenic (As), cadmium $(\mathrm{Cd})$, vanadium $(\mathrm{V})$, manganese $(\mathrm{Mn})$, and nickel $(\mathrm{Ni})$ in 184 elementary schoolchildren ( 99 boys and 85 girls) living in Asaluyeh and compared them with a reference population. The comparisons were done for two seasons (spring and fall). The results showed that in the case area (Asaluyeh), the levels of As, V, Mn, and Ni were significantly higher and that of $\mathrm{Cd}$ was not significantly higher than the reference city for both seasons. The mean concentration of metal(loid)s in Asaluyeh (case) and Sadabad (reference) area as $\mu \mathrm{g} \mathrm{g}^{-1}$ creatinine was
\end{abstract}

Responsible editor: Philippe Garrigues

Electronic supplementary material The online version of this article (https://doi.org/10.1007/s11356-017-9981-6) contains supplementary material, which is available to authorized users.

Bahman Ramavandi

ramavandi_b@yahoo.com; b.ramavandi@bpums.ac.ir

1 Department of Environmental Health Engineering, Faculty of Health and Nutrition, Bushehr University of Medical Sciences,

Bushehr, Iran

2 Department of Biostatistics, Faculty of Health and Nutrition, Bushehr University of Medical Sciences, Bushehr, Iran

3 Environmental Technologies Research Center, Ahvaz Jundishapur University of Medical Sciences, Ahvaz, Iran

4 Department of Environmental Health Engineering, Ahvaz Jundishapur University of Medical Sciences, Ahvaz, Iran

5 Department of Pediatrics, Faculty of Medicine, Bushehr University of Medical Sciences, Bushehr, Iran
As 2.90 and 2.24, V 0.06 and $0.03, \mathrm{Mn} 0.28$ and 0.25 , Ni 0.54 and 0.29 , and $\mathrm{Cd} 0.31$ and 0.28 in spring and $\mathrm{As} 3.08$ and 2.28, V 0.07 and 0.03, Mn 0.30 and 0.26, Ni 0.91 and 0.30, and $\mathrm{Cd} 0.36$ and 0.31 in the fall. Seasonal variations played a key role in determining urinary metal(loid) concentration, as we saw the significant level of $\mathrm{As}, \mathrm{Cd}, \mathrm{V}$, and $\mathrm{Ni}$ in fall than in spring. With regard to the impact of gender on the absorption and accumulation of urinary metal(loid)s, boys showed higher levels of the studied elements, especially for As, than girls as outdoor activities are more popular among boys. Due to the values being lower than those reported in literature, more research is needed on various population groups and other exposure sources in order to judge whether living in the vicinity of the gas and petrochemical industries in Asaluyeh is a threat to nearby residents.

Keywords Asaluyeh area $\cdot$ Schoolchildren $\cdot$ Environmental pollution $\cdot$ Urinary metals and metalloid $\cdot$ Gas and petrochemical industry $\cdot$ Human biomonitoring

\section{Introduction}

The world's second largest natural gas reserve is located beside Asaluyeh City, Iran. The Asaluyeh gas processing plant, which is the biggest refinery in southern Iran, was set up to refine gas from the South Pars gas field. The South Pars gas field was identified in early 1988 and is estimated to have $3.4 \times 10^{12}$ standard $\mathrm{m}^{3}$ of natural gas capacity (Saidi et al. 2014). Today, this gas field contains five refineries in 14 phases (Davoudi et al. 2013). Natural gas from the South Pars field is transported via pipelines to the Asaluyeh gas processing plant, where liquid hydrocarbons are separated. Thus, the emission of pollutants could occur from this 
refinery. Moreover, there are many active petrochemical and downstream companies in the Asaluyeh zone. The refined gas and petrochemical products are stored or piped for transfer to the domestic (internal) market and export purposes as well. Large number of storage tanks, pipelines, and gas flaring besides overhauling and (intentional and unintentional) leakages as well as exports and imports from the industries release a huge amount of pollutants into the environment (Abdollahi et al. 2013; Nadal et al. 2004).

Many researchers (Abdollahi et al. 2013; Kafaei et al. 2017; Nadal et al. 2004, 2007) have clearly reported that the gas and petrochemical industries release pollutants like volatile organic compounds (VOCs) and metals into the environment. Environmental monitoring revealed that the levels of metals in the air, soil, and vegetables in the surrounding areas of the gas and petrochemical companies were higher than those in the reference areas (Abdollahi et al. 2013; Norouzi et al. 2015; Olawoyin et al. 2014; Soriano et al. 2012). Due to their non-biodegradability, ubiquitous distribution, accumulation in the biosphere, and in living organisms, metals pose grave threat to human health, triggering public health concerns (Gumpu et al. 2015). Arsenic (As), cadmium (Cd), vanadium $(\mathrm{V})$, nickel $(\mathrm{Ni})$, and manganese $(\mathrm{Mn})$ are listed in the priority list of hazardous substances by the Agency for Toxic Substances and Disease Registry (ATSDR) (Fay and Mumtaz 1996). Therefore, contamination by these metals remains a great concern across the world due to their potential accumulation in the food chain and living organisms as well as humans living in the surrounding areas, leading to long-term health threats and toxic effects.

Despite rising awareness of the link between environment and human health, the burden of disease in developing countries is increasing due to environmental pollution, and among all the population groups, children face the highest risk (Gopalan 2003). Physiological and behavioural characteristics of children make them more prone to threatening environmental conditions (Sughis et al. 2014). Some studies have exhibited that there is a relationship between metal contamination and health effects (Banerjee et al. 2007; de Burbure et al. 2006; Rangel-Méndez et al. 2016). Human biomonitoring (HBM) is an efficient and cost-effective method of measuring human exposure to chemical substances by referring to takeup values (Angerer et al. 2007), which can reveal the relationship between environmental exposure, body burden, and possible adverse health effects (Černá et al. 2012). Nowadays, different countries, for instance, the USA ( $\mathrm{Li}$ et al. 2008), Germany (Becker et al. 2013), and South Korea (Lee et al. 2012) have used HBM program for monitoring the general population's exposure to environmental pollutants, and these have provided helpful data on the exposure sources and highexposure population groups.

In metal(loid) biomonitoring, different researchers have applied a variety of matrixes such as urine (Aguilera et al. 2010), hair (Md Khudzari et al. 2013), nails (Hussein Were et al. 2008), breast milk (Liu et al. 2013), saliva (de Souza Guerra et al. 2015), meconium (Jiang et al. 2010), semen (Xu et al. 2003), placenta (Al-Saleh et al. 2011), teeth (GdulaArgasińska et al. 2004), bones (Hu et al. 1998), and sweat (Kim et al. 2015). Urine is the preferred non-invasive matrix in metal biomonitoring (Esteban and Castaño 2009), especially in studies on children (Wilhelm et al. 2013), to assess all routes (inhalation, ingestion, and dermal) of exposure (Sughis et al. 2014). The collection, maintenance, and preparation of urine for analysing metal(loid)s are convenient; also, it is possible to determine multiple metals in a small volume of urine (Sughis et al. 2014; Wilhelm et al. 2013).

Lack of adequate HBM data and the absence of enough knowledge of the health effects due to industrial activities on residences close to them in Iran prompted us to establish a study on Asaluyeh area. The study aimed to measure the urinary levels of As, $\mathrm{Cd}, \mathrm{V}, \mathrm{Ni}$, and $\mathrm{Mn}$ among elementary students in Asaluyeh zone in two seasons and compare it with a reference population. The study's results can provide important information for governmental and non-governmental organisations (NGOs) and reference values for exposure to metal(loid)s in the general population. The data could also be beneficial for communities living in the vicinity of gas and petrochemical companies.

\section{Materials and methods}

\section{Area and population study}

The study zone was divided into two areas, case and reference, based on the proximity to the industries and the potential exposure to metal(loid)s. The case area corresponded to Asaluyeh city (in Bushehr Province, Iran) that is located near petrochemical and gas refinery companies (Pars Special Economic Energy Zone). The reference area was Sadabad City (also in Bushehr Province, Iran) which is at a distance of more than $300 \mathrm{~km}$ from the case area that is not effected by the gas and petrochemical companies and/or any emissions and pollutants from other suspected sources and with no natural or man-made source of metals. Figure 1 shows the location of the studied area in Bushehr Province, Iran.

In this study, the target population was 6- to 12-year-old schoolchildren. Schools were the primary sampling units for practical reasons and were chosen to maximise the participation rate. The subjects were randomly selected among each class and were proportional to the total population of each school. There are two elementary school buildings in Asaluyeh — one for girl students and another for boy students. Both schools are situated in one place as a school complex. The average distances of gas and petrochemical sites from the school building are about $2 \mathrm{~km}$ and $7 \mathrm{~km}$, respectively. As 


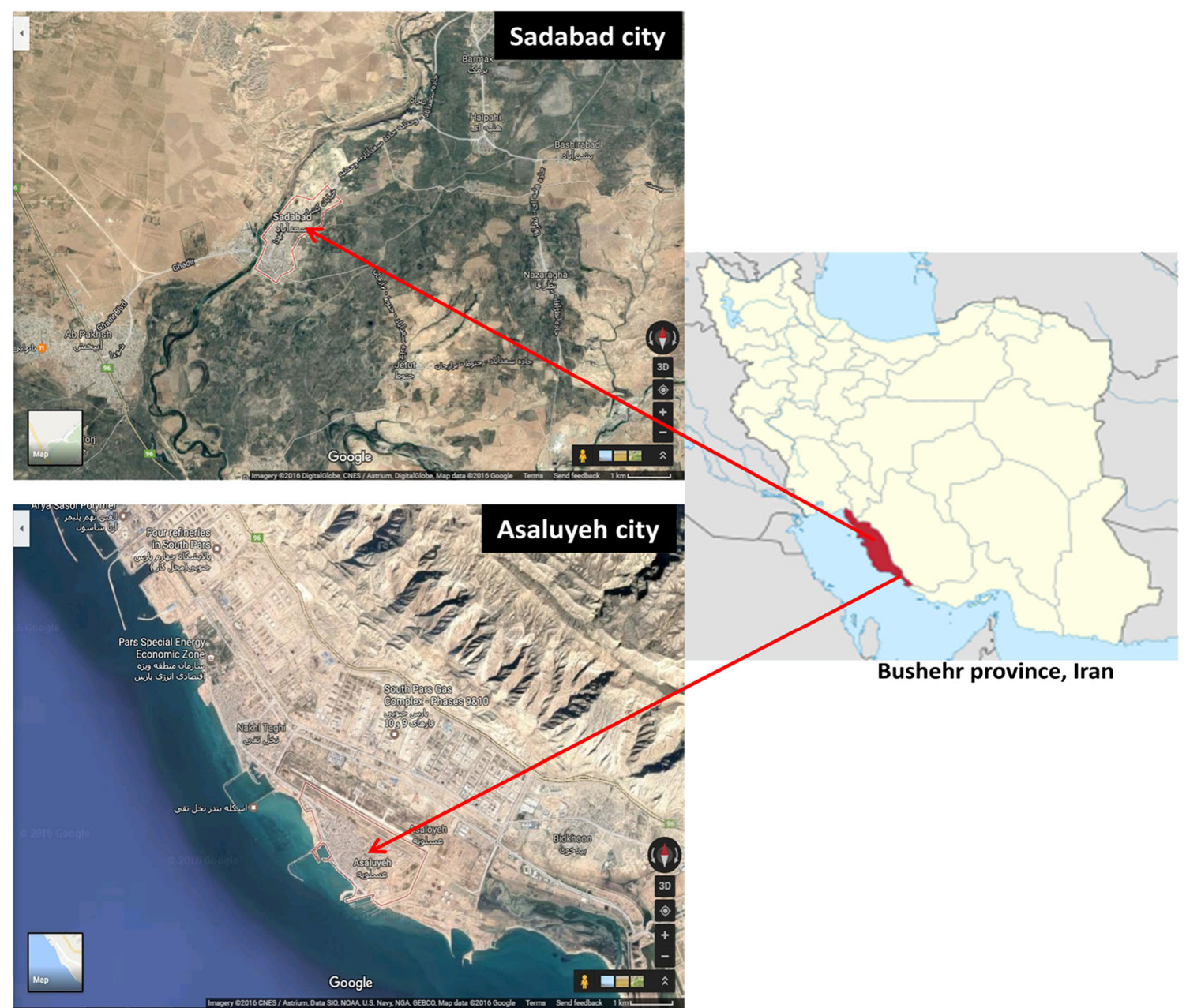

Fig. 1 Location of Asaluyeh area with industrial companies in surrounding and Sadabad City in Bushehr Province, Iran (Image from Google Earth@ software)

Asaluyeh City has a low surface area, the distance between exposed children resident and the suspected sources of pollution was about $2-7.5 \mathrm{~km}$.

The sample size required to detect $30 \%$ mean differences between groups $(\alpha=0.05,1-\beta=0)$ was estimated 180 participants. The total population of elementary students in schools in the case and reference areas were 732 and 749 , respectively. Children who had been living in the study areas for at least 3 consecutive years were eligible for the study. Schoolchildren with kidney and liver dysfunctions and infectious diseases within a month before sample collection and children with iron deficiency and consuming vitamins and supplements were excluded from the sampling groups. This information was derived from children's health records in schools and with the collaboration of school health educators and parents of schoolchildren. Also, schoolchildren who had eaten seafood 3 days before the sampling day have been excluded. None of the children reported smoking by themselves and/or by their parents. Finally, a total of 184 children were selected for participation in each group in this study (i.e. the case and the reference areas). A gender balance was achieved with $54 \%$ of the participants being boys and $46 \%$ girls.

The study was conducted in accordance with the Ethical Principles for Medical Research Involving Human Subjects and was affirmed by Bushehr University of Medical Sciences (ethic code: IR.BPUMS.REC.1395.12). The children's parents gave informed and written consent for participation in the study; the participants were free to withdraw any time during the study; no dangerous or invasive measurements were performed; and confidentiality of the results was guaranteed.

\section{Study period and field work}

The study period was divided into two sampling campaigns (April 2015 and November 2015) to capture the seasonal variations in exposure sources. The children were asked to fill out a self-administrated questionnaire on age, gender, sociodemographic characteristics, parents' occupations, and a history of taking medications. For very young children (6- to 9- 
year- old schoolchildren), the parents were asked to answer the questionnaires and to help them collect urine samples.

Socio-demographic characteristics of exposed and control groups were determined according to the literature (Arrizabalaga et al. 2012). For this purpose, we introduced three categories of high, middle, and low socio-demographic characteristics in the self-administrated questionnaire. The socio-demographic groups were categorised based on the following definitions: (1) high (governmental and company managers, senior officials, members of the liberal professions, senior technicians, managers and owners of trade and personal service companies, skilled technicians, artists, and sportsmen); (2) middle (middle managers, clerks and civil servants, staff of protection, and security services); and (3) low (skilled and semi-skilled workers of industry, trade, services, and unskilled workers) (Arrizabalaga et al. 2012). The data in the self-administrated questionnaire showed that the case and reference groups fell within the low and middle sociodemographic (case $47 \%$ low and 53\% middle, reference $49 \%$ low and $51 \%$ middle). The BMI data (case $15.4 \pm 2.5 \mathrm{~kg} / \mathrm{m}^{2}$ and reference $16.2 \pm 2.4 \mathrm{~kg} / \mathrm{m}^{2}$ ) were collected from the health office of the schools.

\section{Urine collection and analysis}

Spot morning urine was sampled for each schoolchild in $100 \mathrm{~mL}$ sterile and acid-washed polystyrene containers. The schoolchildren and their parents (if they helped the children) were asked to wash their hands before sampling to avoid contamination. Great care was taken to avoid contamination during all the steps of sampling, collection, transport, and analysis. During sampling, all the urine samples were stored at $-20{ }^{\circ} \mathrm{C}$ till the measurement of metal(loid)s. Then, they were defrosted at $4{ }^{\circ} \mathrm{C}$, homogenised (by ultrasonic bath), filtered before being analysed, and divided into two aliquots. One aliquot was used for creatinine determination at the Central Clinical Laboratory of Bushehr University of Medical Sciences and the other was sent for metal(loid) determination at the laboratory of the School of Pharmacy (Shiraz University of Medical Science, Iran) without knowledge of their exact provenance in relation to exposure (blind analysis).

The concentration of $\mathrm{Cd}, \mathrm{V}, \mathrm{Ni}$, and $\mathrm{Mn}$ were measured by an atomic absorption spectrometry-furnace technique (AASFT, PerkinElmer ${ }^{\circledR}$ PinAAcle ${ }^{\mathrm{TM}}$ 900T, Shelton, CT, USA), which was equipped with injection analysis systemhydride generation (FIAS-HG) for As determination. The limits of detection (LOD) were $0.03 \mu \mathrm{g} \mathrm{L}^{-1}$ for $\mathrm{Cd}$, $0.24 \mu \mathrm{g} \mathrm{L}^{-1}$ for Ni, $0.12 \mu \mathrm{g} \mathrm{L}^{-1}$ for $\mathrm{Mn}, 0.11 \mu \mathrm{g} \mathrm{L} \mathrm{L}^{-1}$ for $\mathrm{V}$, and $0.03 \mu \mathrm{g} \mathrm{L}^{-1}$ for As. The standard solution of cadmium, vanadium, nickel, manganese, and arsenic (the highest purity from Merck Co.) was used to prepare the calibration curve. Standard solutions were prepared from a stock solution of $1 \mathrm{~g} \mathrm{~L}^{-1}$ of each studied element by successive dilution with the ultrapure water (resistivity $18.2 \mathrm{M} \Omega \mathrm{cm}$ ). The chemicals used were all purchased at the highest purity available from Merck. Nitric acid (65\%), hydrochloric acid (30\%), magnesium nitrate, palladium nitrate, ammonium dihydrogen phosphate, barium fluoride, and triton X100 were used in the experiment. Blanks were also prepared in the same analytical conditions as the samples. All experiments were repeated twice to be more precise. In an interlaboratory comparison, the metal(loid) content of the samples was re-analysed by AASFT. In both laboratories, the measurements were repeatable. The difference between the measurements of the laboratories for all metal(loid)s was less than 4.3\%-showing the verification of our analysis by AASFT.

To normalise individual variation of urinary sampling and measurement, the metal(loid) concentrations were described by creatinine-adjusted levels ( $\mu \mathrm{g} \mathrm{g}^{-1}$ creatinine) (Roca et al. 2016). Creatinine values below $0.3 \mathrm{~g} \mathrm{~L}^{-1}$ and above $3 \mathrm{~g} \mathrm{~L}^{-1}$ were excluded from the study (Sughis et al. 2014). No creatinine levels were out of this range. Thus, all the urine samples were included in the analysis. All urine analyses were done in a maximum of 10 days after the sampling date. We also analysed urine metal(loid) concentrations as $\mu \mathrm{g} \mathrm{L}^{-1}$ (data are provided in the Supplementary).

\section{Statistical analysis}

The statistical analyses were performed by using the IBM SPSS 22 software (SPSS Inc., IBM Company, Chicago, Ill., USA). Descriptive statistics were carried out on all urinary metal(loid) levels, and the differences between the means of urinary metal(loid) levels from the two study areas, two seasons, and the sexes were tested by using the non-parametric Mann-Whitney test. The non-parametric correlations of variables for the two areas in each season were determined by Spearman's correlation coefficient.

\section{Results}

The number of participants in Asaluyeh (industrialised zone) and the reference area selected was 184, including 85 girls and 99 boys in each area. Table 1 shows the levels of the five elements measured in the urine samples of the schoolchildren from the two studied areas for the two seasons separately. Since the data did not fit a normal distribution, percentiles and geometric means $(\mathrm{Gm})$ are presented for each element. It is obvious from Table 1 that the urinary levels of all the detected metal(loid)s in both areas were above the LOD value. The comparison of metal(loid) levels showed significant differences between the case and the reference areas for all metals except $\mathrm{Cd}$. The metal(loid) levels of $\mathrm{Mn}, \mathrm{V}, \mathrm{Ni}$, and As in the urine of schoolchildren in the case area were 
Table 1 Urinary levels of $\mathrm{Cd}, \mathrm{V}, \mathrm{Ni}, \mathrm{Mn}$, and $\mathrm{As}$ ( $\mu \mathrm{g} \mathrm{g}^{-1}$ creatinine) for the two study populations

\begin{tabular}{|c|c|c|c|c|c|c|c|c|c|c|c|c|}
\hline Season & Element & Place & Number & $\mathrm{Am}(\mathrm{SD})$ & $\mathrm{Gm}$ & Min & $\mathrm{P} 25$ & Median & P75 & P95 & Max & $p$ value \\
\hline \multirow[t]{10}{*}{ Spring } & \multirow[t]{2}{*}{$\mathrm{Cd}$} & Asaluyeh & 184 & $0.31(0.22)$ & 0.22 & 0.02 & 0.12 & 0.29 & 0.42 & 0.72 & 0.97 & \multirow[t]{2}{*}{0.123} \\
\hline & & Reference & 184 & $0.28(0.21)$ & 0.20 & 0.02 & 0.10 & 0.25 & 0.38 & 0.63 & 1.50 & \\
\hline & \multirow[t]{2}{*}{$\mathrm{V}$} & Asaluyeh & 184 & $0.06(0.03)$ & 0.05 & 0.02 & 0.03 & 0.05 & 0.07 & 0.12 & 0.16 & \multirow[t]{2}{*}{$<0.001$} \\
\hline & & Reference & 184 & $0.03(0.02)$ & 0.03 & 0.01 & 0.02 & 0.03 & 0.04 & 0.06 & 0.09 & \\
\hline & \multirow[t]{2}{*}{$\mathrm{Ni}$} & Asaluyeh & 184 & $0.54(0.31)$ & 0.48 & 0.18 & 0.29 & 0.47 & 0.66 & 1.19 & 1.77 & \multirow[t]{2}{*}{$<0.001$} \\
\hline & & Reference & 184 & $0.29(0.16)$ & 0.25 & 0.10 & 0.16 & 0.25 & 0.36 & 0.62 & 0.96 & \\
\hline & \multirow[t]{2}{*}{$\mathrm{Mn}$} & Asaluyeh & 184 & $0.28(0.21)$ & 0.22 & 0.05 & 0.12 & 0.23 & 0.35 & 0.72 & 1.05 & \multirow[t]{2}{*}{0.029} \\
\hline & & Reference & 184 & $0.25(0.18)$ & 0.20 & 0.05 & 0.10 & 0.20 & 0.31 & 0.64 & 0.93 & \\
\hline & \multirow[t]{2}{*}{ As } & Asaluyeh & 184 & $2.90(1.62)$ & 2.48 & 0.35 & 1.79 & 2.82 & 3.53 & 5.76 & 12.00 & \multirow[t]{2}{*}{$<0.001$} \\
\hline & & Reference & 184 & 2.24 (1.39) & 1.89 & 0.29 & 1.46 & 2.30 & 2.86 & 4.03 & 11.82 & \\
\hline \multirow[t]{10}{*}{ Fall } & \multirow[t]{2}{*}{$\mathrm{Cd}$} & Asaluyeh & 184 & $0.36(0.26)$ & 0.26 & 0.03 & 0.14 & 0.34 & 0.51 & 0.83 & 1.10 & \multirow[t]{2}{*}{0.052} \\
\hline & & Reference & 184 & $0.31(0.23)$ & 0.22 & 0.02 & 0.12 & 0.29 & 0.43 & 0.71 & 1.29 & \\
\hline & \multirow[t]{2}{*}{ V } & Asaluyeh & 184 & $0.07(0.04)$ & 0.06 & 0.02 & 0.04 & 0.06 & 0.09 & 0.15 & 0.21 & \multirow[t]{2}{*}{$<0.001$} \\
\hline & & Reference & 184 & $0.03(0.02)$ & 0.03 & 0.01 & 0.02 & 0.03 & 0.04 & 0.07 & 0.10 & \\
\hline & \multirow[t]{2}{*}{$\mathrm{Ni}$} & Asaluyeh & 184 & $0.91(0.41)$ & 0.82 & 0.33 & 0.52 & 0.84 & 1.20 & 1.64 & 3.10 & \multirow[t]{2}{*}{$<0.001$} \\
\hline & & Reference & 184 & $0.30(0.17)$ & 0.26 & 0.10 & 0.16 & 0.26 & 0.37 & 0.67 & 0.98 & \\
\hline & \multirow[t]{2}{*}{$\mathrm{Mn}$} & Asaluyeh & 184 & $0.30(0.22)$ & 0.24 & 0.06 & 0.13 & 0.25 & 0.38 & 0.75 & 1.14 & \multirow[t]{2}{*}{0.015} \\
\hline & & Reference & 184 & $0.26(0.19)$ & 0.21 & 0.05 & 0.11 & 0.21 & 0.33 & 0.67 & 0.97 & \\
\hline & \multirow[t]{2}{*}{ As } & Asaluyeh & 184 & $3.08(1.71)$ & 2.63 & 0.36 & 1.96 & 2.91 & 3.69 & 6.70 & 12.35 & \multirow[t]{2}{*}{$<0.001$} \\
\hline & & Reference & 184 & $2.28(1.41)$ & 1.93 & 0.29 & 1.48 & 2.35 & 2.95 & 4.11 & 12.04 & \\
\hline
\end{tabular}

$A M(S D)$ arithmetic mean (standard deviation); GM geometric mean; Med median; Px percentile x; min minimum; max maximum

significantly higher than those of schoolchildren in the reference area.

Table 2 depicts the seasonal variations of the four metals and one metalloid in the urine of schoolchildren in the case areas. A positive correlation was observed between season and some metal(loid) levels. The levels of $\mathrm{Cd}, \mathrm{V}, \mathrm{Ni}$, and As in the fall season were significantly higher than the analysed levels in spring ( $p$ value $<0.001$ for all these elements). The mean concentrations of $\mathrm{Mn}$ in spring were also lower than in the fall, but this difference was not significant ( $p$ value $>0.05$ ).

The data for both sexes for seasonal metal(loid) concentrations are presented in Table 3. The As concentration in the two seasons and the $\mathrm{Ni}$ concentration in fall among the boys were significantly higher than those for girls $(p$ value $<0.05)$, but

Table 2 Associations between urinary metal concentrations $\left(\mu \mathrm{g} \mathrm{g}^{-1}\right.$ creatinine) in two seasons in Asaluyeh City

\begin{tabular}{lllll}
\hline Element & Number & Season & & $p$ value \\
\cline { 3 - 4 } & & $\begin{array}{l}\text { Spring } \\
\text { Mean (SD) }\end{array}$ & $\begin{array}{l}\text { Fall } \\
\text { Mean (SD) }\end{array}$ & \\
\hline $\mathrm{Cd}$ & 184 & $0.31(0.22)$ & $0.36(0.26)$ & $<0.001$ \\
$\mathrm{~V}$ & 184 & $0.06(0.03)$ & $0.07(0.04)$ & $<0.001$ \\
$\mathrm{Ni}$ & 184 & $0.54(0.31)$ & $0.91(0.41)$ & $<0.001$ \\
$\mathrm{Mn}$ & 184 & $0.28(0.21)$ & $0.30(0.22)$ & 0.347 \\
$\mathrm{As}$ & 184 & $2.90(1.62)$ & $3.08(1.71)$ & $<0.001$ \\
\hline
\end{tabular}

the mean concentrations of $\mathrm{Cd}$ and $\mathrm{Mn}$ metals for boys were not significantly higher than those for girls ( $p$ value $>0.05$ ). The mean concentration of $\mathrm{V}$ was the same for boys and girls in the two seasons.

The Spearman correlation coefficients for metal concentrations in the case area exhibited a positive correlation between $\mathrm{Cd}$ and $\mathrm{V}$ levels in the spring. In the reference population, $\mathrm{Ni}$ and $\mathrm{Mn}$ levels were positively correlated in the two seasons.

Table 3 Associations between urinary metal concentrations ( $\mu \mathrm{g} \mathrm{g}^{-1}$ creatinine) in two sexes in Asaluyeh City

\begin{tabular}{lllll}
\hline Season & Element & \multicolumn{2}{l}{ Sex (n) } & \multirow{2}{*}{$p$ value } \\
\cline { 3 - 4 } & & $\begin{array}{l}\text { Boy (99) } \\
\text { Mean (SD) }\end{array}$ & $\begin{array}{l}\text { Girl (85) } \\
\text { Mean (SD) }\end{array}$ \\
\hline Spring & Cd & $0.32(0.22)$ & $0.30(0.23)$ & 0.344 \\
& V & $0.06(0.03)$ & $0.06(0.03)$ & 0.714 \\
& Ni & $0.56(0.30)$ & $0.52(0.32)$ & 0.248 \\
& Mn & $0.29(0.20)$ & $0.27(0.22)$ & 0.188 \\
& As & $3.26(1.80)$ & $2.49(1.27)$ & $<0.001$ \\
& Cd & $0.37(0.25)$ & $0.36(0.26)$ & 0.501 \\
& V & $0.07(0.04)$ & $0.07(0.04)$ & 0.289 \\
& Ni & $0.97(0.43)$ & $0.83(0.39)$ & 0.025 \\
& Mn & $0.31(0.21)$ & $0.28(0.23)$ & 0.106 \\
& As & $3.48(1.90)$ & $2.62(1.31)$ & 0.001 \\
\hline
\end{tabular}




\section{Discussion}

This study was designed to evaluate the exposure of schoolchildren living in the vicinity of gas and petrochemical complexes in Asaluyeh area, Iran to metal(loid)s emitted from these sites. Since an acceptable range of the amount of metal(loid)s in urine does not exist, we compared the level of urinary creatinine-adjusted metal(loid)s (As, $\mathrm{Cd}, \mathrm{Mn}, \mathrm{Ni}$, and $\mathrm{V}$ ) with the reference population.

We found that children living in the vicinity of the gas and petrochemical industries in Asaluyeh had significantly higher urinary levels of metal(loid)s (As, Mn, Ni, and V) in comparison to the reference group. Table 4 compares our results with those reported in the literature.

Due to the lack of similar studies conducted in neighbouring countries, the results of this study were compared with those undertaken elsewhere in the world. As it can be seen in Table 4, the unit of $\mu \mathrm{g} \mathrm{g}^{-1}$ creatinine was used in the studies to describe the results. The creatinine-adjusted metal(loid)s in the urine is one of the most important predictors to present the level of metal(loid)s in urine (Protano et al. 2016). Compared to the study results of Roca et al. (2016), our metal(loid) levels for As, V, Mn, and $\mathrm{Ni}$ in both the studied areas were far lower than their measured values. Significant differences for the studied elements, except cadmium, in the case and the reference areas demonstrated that urine is a good matrix of recent metal(loid) exposure. Biomonitoring of $\mathrm{Cd}$ metal, with half-life of 15-20 years in the human body, reflects the burden of $\mathrm{Cd}$ on the body and kidneys (Chaumont et al. 2012). In a study of adults living around a petrochemical area which was compared to a reference city in Taiwan, the residents of the contaminated area showed higher values of urinary $\mathrm{As}, \mathrm{Mn}$, and $\mathrm{V}$, but their urinary $\mathrm{Cd}$ level was less than that measured for the reference group, which implies that other variables such as age, alcohol drinking, and smoking were more effective in the distribution of urinary Cd level than exposure to $\mathrm{Cd}$ emitted from petrochemical sites (Yuan et al. 2013).

Low urinary concentration of $\mathrm{Cd}\left(\mathrm{Gm}=0.176 \mu \mathrm{g} \mathrm{g}^{-1}\right.$ creatinine) reported by Roca et al. (2016) was associated with the consumption of dairy products. In contrast, the $\mathrm{Cd}$ level $\left(\mathrm{Gm}=0.53 \mu \mathrm{g} \mathrm{g}^{-1}\right.$ creatinine) reported by Aguilera et al. (2008) showed no association with the diet pattern. The median concentrations of urinary $\mathrm{Cd}$ in children ( $\mathrm{Med}$ $0.37 \mu \mathrm{g} \mathrm{g}^{-1}$ creatinine) reported by Spěváčková et al. (2002) and non-smoking adults (Med $0.32 \mu \mathrm{g} \mathrm{g}^{-1}$ creatinine) studied by Nisse et al. (2016) were similar to our results in the case area. In a comparative study between children and adults, Heitland and Köster (2006) showed an association between increasing age and decreasing level of metals in urine, with the exception of cadmium due to smoking. However, the level of urinary cadmium is still the most reliable biomarker to measure long-term exposure to cadmium, and there is a positive association between kidney $\mathrm{Cd}$ level and urinary $\mathrm{Cd}$ (especially creatinine-adjusted one) (Akerstrom et al. 2013). Not having a significant difference in the Cd levels in the two areas specified the role of covariates in determining the urinary level of Cd.

Soltanieh et al. (2016) pointed out that high volume of pollutants are released from gas flaring in the country, and As was one of the 250 toxic substances emitted from flaring. The significantly higher concentration of As among schoolchildren in Asaluyeh rather than in the reference city (about 30\% higher in both seasons) makes this danger evident; nonetheless, our reported values were far lower than the As reference level (arithmetic mean $(\mathrm{Am})=15.10 \mu \mathrm{g} \mathrm{g}^{-1}$ creatinine) of children reported by Zhang et al. (2016). Heitland and Köster (2006) linked high level of arsenic $\left(\mathrm{Gm}=8.1 \mu \mathrm{g} \mathrm{g}^{-1}\right.$ creatinine) to seafood consumption, but high concentration of As ( $\mathrm{Gm}=101 \mu \mathrm{g} \mathrm{g}^{-1}$ creatinine) found by Sughis et al. (2014) and the low concentration of $\mathrm{As}\left(\mathrm{Gm}=1.6 \mu \mathrm{g} \mathrm{g}^{-1}\right.$ creatinine) reported by Aguilera et al. (2010) were associated with As in drinking water. The value of As $\left(\mathrm{Gm}=2.438 \mu \mathrm{g} \mathrm{g}^{-1}\right.$ creatinine) reported by Molina-Villalba et al. (2015) was close to our measurement. However, there is no accepted specific biomarker for the biomonitoring of inorganic arsenic, a known human carcinogen (Kossowska et al. 2013).

Low dose Mn is essential for the body's metabolic process, but higher doses can pose a health threat. Notwithstanding the statistically higher level of $\mathrm{Mn}$ in the case population compared to reference population, our measured values were far lower than those reported as reference value ( $\mathrm{Am}=7.85 \mu \mathrm{g} \mathrm{g}^{-1}$ creatinine) for children by Zhang et al. (2016). Roca et al. (2016) measured a twofold higher urinary level of $\mathrm{Mn}\left(\mathrm{Gm}=0.43 \mu \mathrm{g} \mathrm{g}^{-1}\right.$ creatinine) in children than the children in our case area. They considered various categories of food and beverages as the main source of Mn exposure. After the comparison with our data, a higher level of Mn (95th percentile $\left(\mathrm{P}_{95}\right)=3.781 \mu \mathrm{g} \mathrm{g}^{-1}$ creatinine) was reported by Molina-Villalba et al. (2015) for a population living close to an agricultural area. A study on children by Heitland and Köster (2006) reported $\mathrm{P}_{95}=0.248 \mu \mathrm{g} \mathrm{g}^{-1}$ creatinine (much less than our reference group), which decreased with age. Gil et al. (2011) studied an occupationally exposed adult population and reported lower $\mathrm{Gm}$ for urinary $\mathrm{Mn}$ $\left(\mathrm{Gm}=0.18 \mu \mathrm{g} \mathrm{g}^{-1}\right.$ creatinine) than those obtained in our study.

Urinary $\mathrm{Ni}$ is a major biomarker to assess $\mathrm{Ni}$ exposure. $\mathrm{Ni}$ exposure mainly occurs through air, diet, and drinking water (Roca et al. 2016). According to Table 4, the children in our study showed lower urinary Ni level than those in other studies, but the mean level of Ni was significantly higher in the case area than the reference area (twofold higher in spring and threefold higher in fall). As per literature, nickel is one of the major components of gas and petrochemical industries, and consequently, it is an unavoidable element in emissions from these industries (Soltanieh et al. 2016). Alimonti et al. (2000) reported 


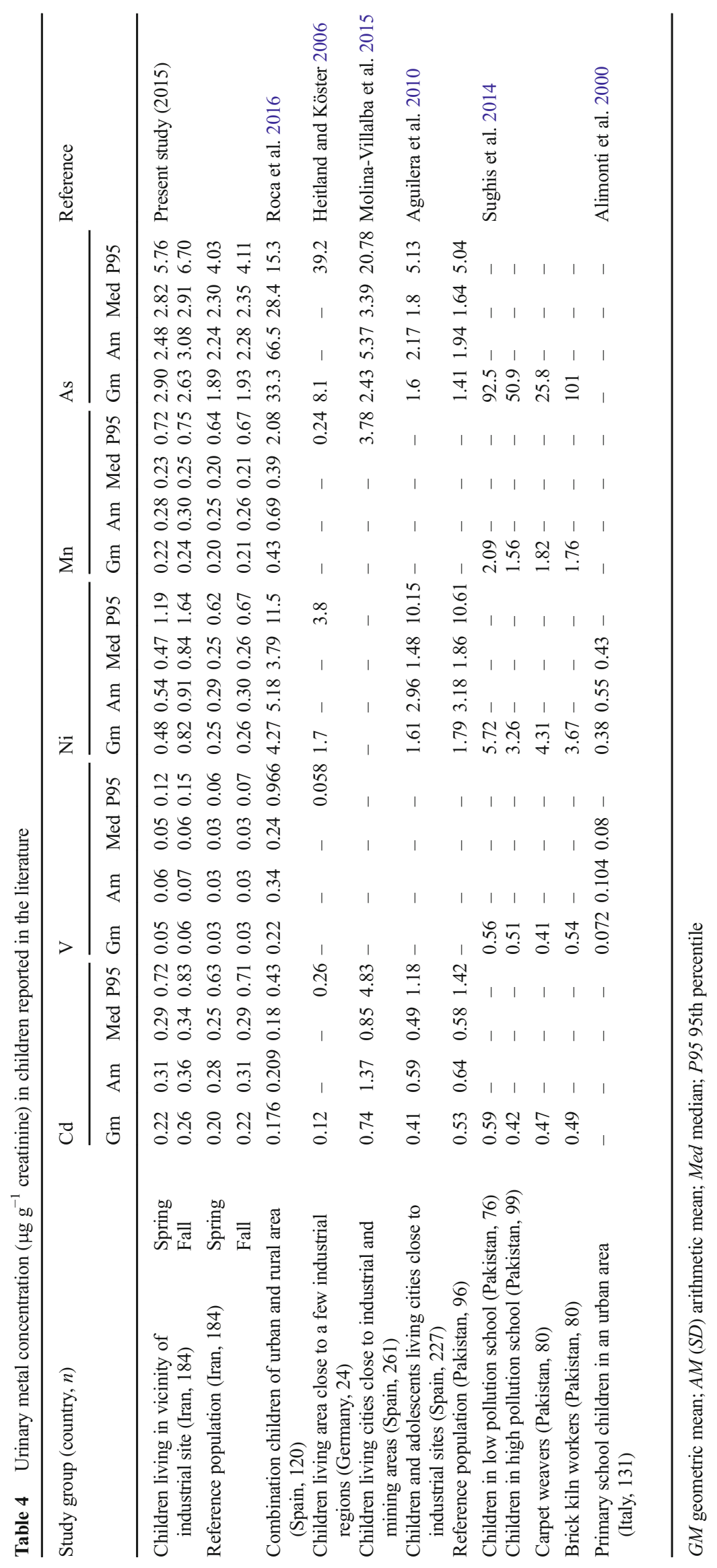


$\mathrm{Gm}=0.386 \mu \mathrm{g} \mathrm{g}^{-1}$ creatinine as reference level of urinary $\mathrm{Ni}$ in children, which was lower than our case area value, but our reference level of As was lower than their reported level. In a population of adults studied by Aguilera et al. (2008) in the vicinity of industrial sources and the reference group, the $\mathrm{Gm}$ of urinary Ni levels were 1.15 and $1.42 \mu \mathrm{g} \mathrm{g}^{-1}$ creatinine, respectively. They also reported that although cigarettes included $\mathrm{Ni}$, smoking did not clearly affect urinary Ni. Wilhelm et al. (2013) reported higher values of urinary $\mathrm{Ni}$ in 3- to 14-year-old children $\left(\mathrm{Gm}=1.20 \mu \mathrm{g} \mathrm{g}^{-1}\right.$ creatinine) than the current study, and they also noted that the creatinine-adjusted $\mathrm{Ni}$ in urine decreased with age in children.

The element $\mathrm{V}$ is an integral part of pollution from gas and petrochemical industries (Soltanieh et al. 2016). The inhalation of particles originating from petrochemical activities is the main route for environmental exposure to vanadium (Fortoul et al. 2014). The soils around petrochemical sites showed higher level of $\mathrm{V}$ than natural environments (Imtiaz et al. 2015). Urine is the route for $\mathrm{V}$ excretion. After adjusting the confounding variables between exposure and non-exposure groups, Yuan et al. (2013) concluded that urinary $\mathrm{V}$ was one of the most important biomarkers for biomonitoring of pollutant exposure in the vicinity of gas and petrochemical industries. Despite the proximity to these industries, however, our case population showed lower concentrations of $\mathrm{V}$ than that considered as a reference for children in the studies by Alimonti et al. (2000) (Am $=0.104 \mu \mathrm{g} \mathrm{g}^{-1}$ creatinine) and Zhang et al. (2016) ( $\mathrm{Am}=2.44 \mu \mathrm{g} \mathrm{g}^{-1}$ creatinine); nonetheless, we measured twofold higher concentration of urinary vanadium in the case population than the reference population in both seasons. Our population of children in both the case and the reference areas showed lower concentrations of V than Roca et al. (2016), who recommended that food was the main predictor of the urinary $\mathrm{V}$ level. The measured $\mathrm{P}_{95}$ of $\mathrm{V}$ concentration in the study by Heitland and Köster (2006) was close to the measurements of our reference group. MacGregor and Du (2014) reported that occupational exposure to $\mathrm{V}$ could influence neurobehavioral functions. The differences between the $\mathrm{V}$ levels in our study and those mentioned by others could be due to the V level absorption from other routes, types, and amounts of pollutants from emitter industries, diet, and habits.

Seasonal variations showed a great effect on the creatinineadjusted metal(loid) values measured in urine as we saw significantly higher levels of $\mathrm{Cd}, \mathrm{V}, \mathrm{Ni}$, and $\mathrm{As}$ in fall than in spring. Changes in man-made source processes due to seasonal variations and weather like residential fossil fuel burning and construction operations (Norouzi et al. 2017) impact on soil can affect the distribution of metal concentration in the environment and thus the human body (Kim et al. 2014;
Laidlaw et al. 2005). Furthermore, Aguilera et al. (2008) reported that seasonal variations of exposure sources such as diet or pollution level were known as a potential confounder for biomonitoring of urinary metals. Their results were similar to our findings, as $\mathrm{Ni}, \mathrm{As}$, and $\mathrm{Cd}$ were higher in fall than in spring. It is evident from our results that metal(loid) exposure in the two regions is equally affected by seasonal variations since comparison between the measured values and the two areas has undergone a similar trend of significance in both seasons. The urine metal(loid) concentrations in both areas were similar and followed the decreasing order: $\mathrm{As}>\mathrm{Ni}>\mathrm{Cd}>\mathrm{Mn}>\mathrm{V}$ (both seasons).

Temperature changes, humidity percentage, the amount of drinking water, and rainfall can influence environmental exposure trends and absorption levels of metal(loid)s. In some previous research, however, seasonal variations did not affect urinary creatinine levels (Hansen et al. 2001).

Gender is an effective factor in determining creatinineadjusted metals (Morton et al. 2014). Our results showed higher concentrations of metal(loid)s in boys than in girls, especially for As the in two seasons. Molina-Villalba et al. (2015) noted that there was a positive association between urinary As level and high physical activities of children. Kordas et al. (2010) detected lower concentration of As in girls than in boys. They justified this finding as boys like outdoor activities and they spend more time in playgrounds and other contaminated places. We can extend this conclusion to the whole of our observations about gender differences in metal(loid) exposure. On the opposite side, Varrica et al. (2014) reported that females are more exposed to metal than males, and this difference becomes more pronounced with age. Iron deficiency and sex hormone function are factors that increase biosorption of metal(loid)s and bioaccumulation in females, but this did not influence the girl population in our study (girls before menarche) (Kresovich et al. 2015; Protano et al. 2016; Tellez-Plaza et al. 2010).

We do not have a compelling reason to explain the positive correlation between urinary $\mathrm{Cd}$ and $\mathrm{V}$ in the case area and urinary $\mathrm{Mn}$ and $\mathrm{Ni}$ in the reference area by the present information without any data on the other sources of exposure, but we can assume that they are associated with similar exposure routes such as air, soil, drinking water, and diet.

Studies conducted on children residing close to petrochemical sites have focused primarily on the acute effects of dealing with pollutants emitted from these sites such as pulmonary function disorders (Brand et al. 2016; Kampeerawipakorn et al. 2017). The effects of metal(loid) exposure due to chronic exposure are not clear. However, their subsequent effects are evident due to the cumulative properties of these substances in the body. A wide attention to seasonal variations for assessing the exposure to and accumulation of metal(loid)s in the bodies of children is the strength of this work. 


\section{Conclusion}

In this study, we determined urinary levels of arsenic (As), cadmium $(\mathrm{Cd})$, vanadium $(\mathrm{V})$, manganese $(\mathrm{Mn})$, and nickel (Ni) in 184 elementary schoolchildren living in the vicinity of gas and petrochemical industrial activity in the Asaluyeh, Iran. The measurement of metal(loid) values in urine showed the association to the sampling season. Owing to metabolic differences and more activities, boys reflected higher levels of metal(loid)s compared to girls. Overall, the urinary levels of $\mathrm{As}, \mathrm{V}, \mathrm{Mn}$, and $\mathrm{Ni}$ in the children living near the industrial area were higher than the levels in the reference population, but that does not mean there is a problem because the urinary levels in other studies were higher.

Acknowledgements The present paper was extracted from MSc. thesis of R. Kafaei, a student of Bushehr University of Medical Sciences (BPUMS); the financial support from BPUMS (Grant no. 1392-H-114) to conduct this work is appreciated. The kind collaboration of the schoolchildren's parents and school staff of Asaluyeh and Sadabad, Iran, is gratefully acknowledged.

\section{Compliance with ethical standards}

Conflict of interests The authors declare that they have no conflict of interests.

Statement of ethical approval The study was conducted in accordance with the Ethical Principles for Medical Research Involving Human Subjects and was affirmed by Bushehr University of Medical Sciences (ethic code: IR.BPUMS.REC.1395.12).

\section{References}

Abdollahi S, Raoufi Z, Faghiri I, Savari A, Nikpour Y, Mansouri A (2013) Contamination levels and spatial distributions of heavy metals and PAHs in surface sediment of Imam Khomeini Port, Persian Gulf, Iran. Mar Pollut Bull 71:336-345

Aguilera I, Daponte A, Gil F, Hernández AF, Godoy P, Pla A, Ramos JL (2008) Biomonitoring of urinary metals in a population living in the vicinity of industrial sources: a comparison with the general population of Andalusia, Spain. Sci Total Environ 407:669-678

Aguilera I, Daponte A, Gil F, Hernández AF, Godoy P, Pla A, Ramos JL (2010) Urinary levels of arsenic and heavy metals in children and adolescents living in the industrialised area of Ria of Huelva (SW Spain). Environ Int 36:563-569

Akerstrom M, Barregard L, Lundh T, Sallsten G (2013) The relationship between cadmium in kidney and cadmium in urine and blood in an environmentally exposed population. Toxicol Appl Pharmacol 268: 286-293

Alimonti A, Petrucci F, Krachler M, Bocca B, Caroli S (2000) Reference values for chromium, nickel and vanadium in urine of youngsters from the urban area of Rome. J Environ Monit 2:351-354

Al-Saleh I, Shinwari N, Mashhour A, Mohamed GED, Rabah A (2011) Heavy metals (lead, cadmium and mercury) in maternal, cord blood and placenta of healthy women. Int J Hyg Environ Health 214:79101

Angerer J, Ewers U, Wilhelm M (2007) Human biomonitoring: state of the art. Int J Hyg Environ Health 210:201-228
Arrizabalaga JJ, Larrañaga N, Espada M, Amiano P, Bidaurrazaga J, Latorre K, Gorostiza E (2012) Changes in iodine nutrition status in schoolchildren from the Basque Country. Endocrinología y Nutrición (English Edition) 59:474-484

Banerjee TD, Middleton F, Faraone SV (2007) Environmental risk factors for attention-deficit hyperactivity disorder. Acta Paediatr 96:12691274

Becker K et al (2013) German health-related environmental monitoring: assessing time trends of the general population's exposure to heavy metals. Int J Hyg Environ Health 216:250-254

Brand A, McLean KE, Henderson SB, Fournier M, Liu L, Kosatsky T, Smargiassi A (2016) Respiratory hospital admissions in young children living near metal smelters, pulp mills and oil refineries in two Canadian provinces. Environ Int 94:24-32

Černá M, Krsková A, Čejchanová M, Spěváčková V (2012) Human biomonitoring in the Czech Republic: an overview. Int J Hyg Environ Health 215:109-119

Chaumont A, Nickmilder M, Dumont X, Lundh T, Skerfving S, Bernard A (2012) Associations between proteins and heavy metals in urine at low environmental exposures: evidence of reverse causality. Toxicol Lett 210:345-352

Davoudi M, Rahimpour M, Jokar S, Nikbakht F, Abbasfard H (2013) The major sources of gas flaring and air contamination in the natural gas processing plants: a case study. J Nat Gas Sci Eng 13:7-19

de Burbure $C$ et al (2006) Renal and neurologic effects of cadmium, lead, mercury, and arsenic in children: evidence of early effects and multiple interactions at environmental exposure levels. Environ Health Perspect 114:584-590

de Souza GC et al (2015) Lead concentrations in whole blood, serum, saliva and house dust in samples collected at two time points (12 months apart) in Santo Amaro, BA, Brazil. Environ Res 142:337344

Esteban M, Castaño A (2009) Non-invasive matrices in human biomonitoring: a review. Environ Int 35:438-449

Fay RM, Mumtaz MM (1996) Development of a priority list of chemical mixtures occurring at 1188 hazardous waste sites, using the hazdat database. Food Chem Toxicol 34:1163-1165

Fortoul T et al (2014) Overview of environmental and occupational vanadium exposure and associated health outcomes: an article based on a presentation at the 8th International Symposium on Vanadium Chemistry, Biological Chemistry, and Toxicology, Washington DC, August 15-18, 2012. J Immunotoxicol 11:13-18

Gdula-Argasińska J, Appleton J, Sawicka-Kapusta K, Spence B (2004) Further investigation of the heavy metal content of the teeth of the bank vole as an exposure indicator of environmental pollution in Poland. Environ Pollut 131:71-79

Gil F, Hernández AF, Márquez C, Femia P, Olmedo P, López-Guarnido O, Pla A (2011) Biomonitorization of cadmium, chromium, manganese, nickel and lead in whole blood, urine, axillary hair and saliva in an occupationally exposed population. Sci Total Environ 409: $1172-1180$

Gopalan HN (2003) Environmental health in developing countries: an overview of the problems and capacities. Environ Health Perspect 111:A446

Gumpu MB, Sethuraman S, Krishnan UM, Rayappan JBB (2015) A review on detection of heavy metal ions in water - an electrochemical approach. Sensors Actuators B Chem 213:515-533

Hansen ÅM, Garde AH, Skovgaard LT, Christensen JM (2001) Seasonal and biological variation of urinary epinephrine, norepinephrine, and cortisol in healthy women. Clin Chim Acta 309:25-35

Heitland P, Köster HD (2006) Biomonitoring of 30 trace elements in urine of children and adults by ICP-MS. Clin Chim Acta 365:310-318

Hu H, Rabinowitz M, Smith D (1998) Bone lead as a biological marker in epidemiologic studies of chronic toxicity: conceptual paradigms. Environ Health Perspect 106:1 
Hussein Were F, Njue W, Murungi J, Wanjau R (2008) Use of human nails as bio-indicators of heavy metals environmental exposure among school age children in Kenya. Sci Total Environ 393:376384

Imtiaz M et al (2015) Vanadium, recent advancements and research prospects: a review. Environ Int 80:79-88

Jiang C-B, Yeh C-Y, Lee H-C, Chen M-J, Hung F-Y, Fang S-S, Chien LC (2010) Mercury concentration in meconium and risk assessment of fish consumption among pregnant women in Taiwan. Sci Total Environ 408:518-523

Kafaei $\mathrm{R}$ et al (2017) Data on metals biomonitoring in the body of schoolchildren in the vicinity of a heavily industrialized site. Data Brief 12:405-408

Kampeerawipakorn O et al (2017) Health risk evaluation in a population exposed to chemical releases from a petrochemical complex in Thailand. Environ Res 152:207-213

Kim K-H, Shon Z-H, Mauulida PT, Song S-K (2014) Long-term monitoring of airborne nickel $(\mathrm{Ni})$ pollution in association with some potential source processes in the urban environment. Chemosphere 111:312-319

Kim J et al (2015) Wearable temporary tattoo sensor for real-time trace metal monitoring in human sweat. Electrochem Commun 51:41-45

Kordas K, Queirolo EI, Ettinger AS, Wright RO, Stoltzfus RJ (2010) Prevalence and predictors of exposure to multiple metals in preschool children from Montevideo, Uruguay. Sci Total Environ 408:4488-4494

Kossowska B, Dudka I, Gancarz R, Antonowicz-Juchniewicz J (2013) Application of classic epidemiological studies and proteomics in research of occupational and environmental exposure to lead, cadmium and arsenic. Int J Hyg Environ Health 216:1-7

Kresovich JK, Argos M, Turyk ME (2015) Associations of lead and cadmium with sex hormones in adult males. Environ Res 142:25-33

Laidlaw MA, Mielke HW, Filippelli GM, Johnson DL, Gonzales CR (2005) Seasonality and children's blood lead levels: developing a predictive model using climatic variables and blood lead data from Indianapolis, Indiana, Syracuse, New York, and New Orleans, Louisiana (USA). Environ Health Perspect 113:793-800

Lee JW et al (2012) Korea national survey for environmental pollutants in the human body 2008: heavy metals in the blood or urine of the Korean population. Int J Hyg Environ Health 215:449-457

Li Z, Sandau CD, Romanoff LC, Caudill SP, Sjodin A, Needham LL, Patterson DG (2008) Concentration and profile of 22 urinary polycyclic aromatic hydrocarbon metabolites in the US population. Environ Res 107:320-331

Liu K-S et al (2013) Breast milk lead and cadmium levels in suburban areas of Nanjing, China. Chin Med Sci J 28:7-15

MacGregor JA, Du H (2014) Re: vanadium exposure-induced neurobehavioral alterations among Chinese workers Li et al. (2013). Neurotoxicology 44:369

Md Khudzari J, Wagiran H, Hossain I, Ibrahim N (2013) Screening heavy metals levels in hair of sanitation workers by X-ray fluorescence analysis. J Environ Radioact 115:1-5

Molina-Villalba I, Lacasaña M, Rodríguez-Barranco M, Hernández AF, Gonzalez-Alzaga B, Aguilar-Garduño C, Gil F (2015) Biomonitoring of arsenic, cadmium, lead, manganese and mercury in urine and hair of children living near mining and industrial areas. Chemosphere 124:83-91

Morton J, Tan E, Leese E, Cocker J (2014) Determination of 61 elements in urine samples collected from a non-occupationally exposed UK adult population. Toxicol Lett 231:179-193

Nadal M, Schuhmacher M, Domingo JL (2004) Metal pollution of soils and vegetation in an area with petrochemical industry. Sci Total Environ 321:59-69

Nadal M, Schuhmacher M, Domingo JL (2007) Levels of metals, PCBs, PCNs and PAHs in soils of a highly industrialized chemical/ petrochemical area: temporal trend. Chemosphere 66:267-276
Nisse C, Tagne-Fotso R, Howsam M, Richeval C, Labat L, Leroyer A (2016) Blood and urinary levels of metals and metalloids in the general adult population of Northern France: the IMEPOGE study, 2008-2010. Int J Hyg Environ Health. https://doi.org/10.1016/j. ijheh.2016.09.020

Norouzi S, Khademi H, Faz Cano A, Acosta JA (2015) Using plane tree leaves for biomonitoring of dust borne heavy metals: a case study from Isfahan, Central Iran. Ecol Indic 57:64-73

Norouzi S, Khademi H, Ayoubi S, Faz Cano A, Acosta JA (2017) Seasonal and spatial variations in dust deposition rate and concentrations of dust-borne heavy metals, a case study from Isfahan, central Iran. Atmos Pollut Res 8:686-699

Olawoyin R, Heidrich B, Oyewole S, Okareh OT, McGlothlin CW (2014) Chemometric analysis of ecological toxicants in petrochemical and industrial environments. Chemosphere 112:114-119

Protano C, Astolfi ML, Canepari S, Vitali M (2016) Urinary levels of trace elements among primary school-aged children from Italy: the contribution of smoking habits of family members. Sci Total Environ 557:378-385

Rangel-Méndez JA, Arcega-Cabrera FE, Fargher LF, Moo-Puc RE (2016) Mercury levels assessment and its relationship with oxidative stress biomarkers in children from three localities in Yucatan, Mexico. Sci Total Environ 543:187-196

Roca M, Sánchez A, Pérez R, Pardo O, Yusà V (2016) Biomonitoring of 20 elements in urine of children. Levels and predictors of exposure. Chemosphere 144:1698-1705

Saidi M, Siavashi F, Rahimpour M (2014) Application of solid oxide fuel cell for flare gas recovery as a new approach; a case study for Asalouyeh gas processing plant, Iran. J Nat Gas Sci Eng 17:13-25

Soltanieh M, Zohrabian A, Gholipour MJ, Kalnay E (2016) A review of global gas flaring and venting and impact on the environment: case study of Iran. Int J Greenhouse Gas Control 49:488-509

Soriano A, Pallarés S, Pardo F, Vicente AB, Sanfeliu T, Bech J (2012) Deposition of heavy metals from particulate settleable matter in soils of an industrialised area. J Geochem Explor 113:36-44

Spěváčková V, Čejchanová M, Černá M, Spěváček V, Šmíd J, Beneš B (2002) Population-based biomonitoring in the Czech Republic: urinary arsenic. J Environ Monit 4:796-798

Sughis M, Nawrot TS, Riaz A, Ikram-Dar U, Mahmood A, Haufroid V, Nemery B (2014) Metal exposure in schoolchildren and working children. A urinary biomonitoring study from Lahore, Pakistan. Int J Hyg Environ Health 217:669-677

Tellez-Plaza M, Navas-Acien A, Crainiceanu CM, Sharrett AR, Guallar E (2010) Cadmium and peripheral arterial disease: gender differences in the 1999-2004 US National Health and Nutrition Examination Survey. Am J Epidemiol 172:671-681

Varrica D et al (2014) Metals and metalloids in hair samples of children living near the abandoned mine sites of Sulcis-Inglesiente (Sardinia, Italy). Environ Res 134:366-374

Wilhelm M et al (2013) Levels and predictors of urinary nickel concentrations of children in Germany: results from the German Environmental Survey on children (GerES IV). Int J Hyg Environ Health 216:163-169

Xu D-X, Shen H-M, Zhu Q-X, Chua L, Wang Q-N, Chia S-E, Ong C-N (2003) The associations among semen quality, oxidative DNA damage in human spermatozoa and concentrations of cadmium, lead and selenium in seminal plasma. Mutat Res Genet Toxicol Environ Mutagen 534:155-163

Yuan T, Pien W, Chan C (2013) Urinary heavy metal levels of residents in the vicinity of a petrochemical complex in Taiwan. Published by EDP sciences. http://www.e3s-Conferences.Org. Accessed 2103

Zhang X, Cui X, Lin C, Ma J, Liu X, Zhu Y (2016) Reference levels and relationships of nine elements in first-spot morning urine and 24-h urine from 210 Chinese children. Int J Hyg Environ Health. https:// doi.org/10.1016/j.ijheh.2016.10.013 